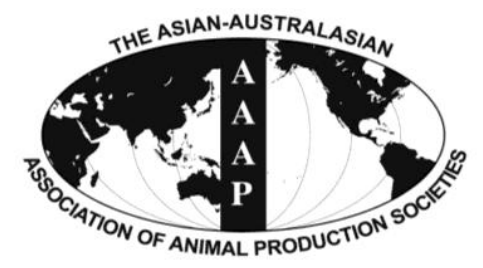

Asian Australas. J. Anim. Sci.

Vol. 26, No. 8 : 1080-1088 August 2013

http://dx.doi.org/10.5713/ajas.2013.13014

www.ajas.info

pISSN 1011 -2367 elSSN 1976-5517

\title{
Kisspeptin-10 Enhanced Egg Production in Quails Associated with the Increase of Triglyceride Synthesis in Liver
}

\author{
J. Wu, W. Fu, Y. Huang, Y. Ni*, and R. Zhao \\ Key Laboratory of Animal Physiology \& Biochemistry, Nanjing Agricultural University, Nanjing 210095, China
}

\begin{abstract}
Our previous results showed that kisspeptin-10 (Kp-10) injections via intraperitoneal (i.p.) once daily for three weeks notably promoted the egg laying rate in quails. In order to investigate the mechanism behind the effects of Kp-10 on enhancing the egg laying rate in birds, this study focused on the alternations of lipids synthesis in liver after Kp-10 injections. 75 female quails (22 d of age) were allocated to three groups randomly, and subjected to 0 (control, Con), $10 \mathrm{nmol}$ (low dosage, L) and $100 \mathrm{nmol}$ (high dosage, $\mathrm{H}$ ) $\mathrm{Kp}-10$ injections via i.p. once daily for three weeks, respectively. At d 52, quails were sacrificed and sampled for further analyses. Serum $\mathrm{E}_{2}$ concentration was increased by $\mathrm{Kp}-10$ injections, and reached statistical significance in $\mathrm{H}$ group. Serum triglyceride (TG) concentrations were increased by $46.7 \%$ in L group and $36.8 \%$ in H group, respectively, but did not reach statistical significance, and TG contents in liver were significantly elevated by Kp-10 injections in a dose-dependent manner. Serum total cholesterol (Tch) concentrations significantly decreased in $\mathrm{H}$ group, while in $\mathrm{H}$ group the hepatic Tch content was markedly increased. The level of nonesterified fatty acid (NEFA), apolipoprotein A1 and B (apoA1 and apoB) were not altered by Kp-10 injections. The genes expression of sterol regulatory element binding protein-1 (SREBP-1), fatty acid synthetase (FAS), apolipoprotein VLDL-II (apoVLDL-II), cholesterol $7 \alpha$-hydroxylase (CYP7A1) and vitellogenin II (VTG-II) were significantly up-regulated by high but not low dosage of Kp-10 injection compared to the control group. However, the expression of SREBP-2, acetyl-CoA carboxylase (ACC $)_{\alpha}$, malic enzyme (ME), stearoylCoA $(\Delta 9)$ desaturase 1 (SCD1), apolipoprotein A1 (apoA1), fatty acid binding protein 2 (FABP2), 3-hydroxyl-3-methyl glutarylcoenzyme A reductases (HMGCR), estrogen receptor $\alpha, \beta$ (ER $\alpha$ and $\beta$ ) mRNA were not affected by Kp-10 treatment. In line with hepatic mRNA abundance, hepatic SREBP1 protein content was significantly higher in $\mathrm{H}$ group. Although the mRNA expression was not altered, the content of ER $\alpha$ protein in liver was also significantly increased in $\mathrm{H}$ group. However, SREBP-2 protein content in liver was not changed by Kp-10 treatment. In conclusion, exogenous Kp-10 consecutive injections during juvenile stage significantly advanced the tempo of egg laying in quails, which was associated with the significant elevation in hepatic lipids synthesis and transport. (Key Words: Kisspeptin-10, Egg Laying, Triglyceride, Liver, Quail)
\end{abstract}

\section{INTRODUCTION}

It's well documented that kisspeptin/G protein-coupled receptor 54 (GPR54) signal system is a pivotal signal pathway to regulate gonadotrophin releasing hormone $(\mathrm{GnRH})$ secreting from hypothalamus and then to control the onset of normal puberty (Seminara et al., 2003). The importance of kisspeptin in normal reproductive maturation has been demonstrated by the observations that mutations in either the Kiss-1 gene or its cognate receptor Kiss-1R gene render the animal unable to reach puberty (de Roux., 2003; d'Anglemont et al., 2007). In contrast, injection of kisspeptin causes the sexual precosity, and kisspeptins are

\footnotetext{
* Corresponding Author: Y. D. Ni. Tel: +86-2584399020, Fax: +86-2584398669, E-mail: niyingdong@njau.edu.cn Submitted Jan. 6, 2013; Accepted Mar. 18, 2013; Revised Apr. 11, 2013
}

likely the most potent elicitors of GnRH/gonadotropin secretion known so far (Roa et al., 2009). Studies on rodents and primates showed that the expression of kiss-1 gene and protein was up-regulated in hypothalamus during reproductive puberty development (Han et al., 2005; Clarkson and Herbison, 2006; Keen et al., 2008), and further activated in response to exogenous sex steroids (Smith et al., 2005). These findings proved kisspeptin as an important internal signal to control the initiation and maintenance of reproduction.

The avian neuroendocrine and endocrine system is very similar to the mammalian system (Wingfield, 2005). As in mammals, the avian reproduction is controlled by the axis of hypothalamus-pituitary gonad (HPG) and the secretion of GnRH from hypothalamus is the key step for initiating the reproduction. Although there is no evidence for a Kiss-like 
gene in birds and this gene has been suggested to have been lost in avian species during evolution (Um et al., 2010). Saldanha et al. (2010) reported that neurons that express kisspeptin-like immunoreactive (ir) protein were observed in the medial preoptic nucleus (POM) of hypothalamus in mallard drake (Saldanha et al., 2010). Kisspeptin central administration with low doses was sufficient to increase plasma LH levels in the drake and the white-crowned sparrows (Saldanha et al., 2010; Charlier et al., 2011). Our previous studies also showed that kisspeptin immunoreactive substance is expressed in ovarian granulosa cells of hens, and kisspeptin-10 stimulated progesterone secretion in cultured hens' granulosa cells from preovulatory follicles (Xiao et al., 2011). These observations suggest the highly conserved function of kisspeptins in regulating reproduction across the vertebrates. However, till now, the data about the effects of kisspeptins on the avian reproduction is really scarce.

It is generally accepted that the onset of egg laying in female poultry is the indicator of puberty complement and sex maturation, and the reproductive behavior is mainly regulated by hormones secreted from HPG axis (Gous et al., 2000). In chicken each egg yolk contains about 4 gram of triglycerides (TG) (Bujo et al., 1997), thus egg production is an energy-intensive process, requiring a large increase in TG synthesis to support the demands of new yolk formation. Birds have the ability to store large quantities of excess energy (in the form of TG) in liver, adipose tissue and in yolk of developing oocytes (Hermier, 1997). The liver is known to be the primary site for lipogenesis in birds, and most of the body's endogenous lipids are hepatic origin $(\mathrm{Xu}$ et al., 2003). As in mammals, enzymes in the avian liver control sterol and lipid metabolism, and the levels of mRNA expression of lipogenic genes have been reported to parallel changes in enzyme activity, such as fatty acid synthase (FAS) (Wilson et al., 1986).

Several mature peptides encoded by kiss-1 gene including kisspeptin-54, -14, -13 and -10 , all of their carboxyl terminus is a motif of arginine-phenylalanine- $\mathrm{NH} 2$ (RF-NH2), and each can activate GPR54 with equal biopotency (Kotani et al., 2001; Oakley et al., 2009). The amino acids sequence and the function of kisspeptin-10 is highly conserved among different species, including human, rat, mouse and fish (van Aerle et al., 2008). Therefore, the aim of this study was to investigate the effect of Kp-10 consecutive injection via i.p. on the initiation of egg laying in Japanese quails. The Japanese quail has been suggested as a good model for studying reproductive aging of hypothalamic systems (Ottinger et al., 2004), and an ideal species for studies of the neuroendocrine control of reproduction and sexual behavior due to the small size and early sexual maturation. To uncover the mechanism behind the effects of Kp-10 on the onset of egg laying in birds, this study focused on the changes of cholesterol and TG synthesis in liver and transport in peripheral system, with particular emphasis on the genes expression involved in fatty acid synthesis and cholesterol metabolism.

\section{MATERIAL AND METHODS}

\section{Animals}

Seventy-five female Japanese quails were obtained from a local breeding farm (Wuxi, China) and fed following the standard procedure. Quails were allowed to water ad libitum during the whole experimental stage. At $7 \mathrm{~d}$ of age, quails were randomly allocated to 15 cages ( 5 quails in each cage) and raised in the same place and management as well as the same diet. At $21 \mathrm{~d}$ of age, 15 cages were randomly divided to three groups (5 cages for each group) and subjected to $300 \mu \mathrm{l}$ saline injection with or without Kp-10 (Cat. No. 2570, TOCRIS, USA). $300 \mu$ saline without Kp10 (control, Con), low (10 nmol, L) or high (100 nmol, H) $\mathrm{Kp}$-10 was injected to juvenile quails via i.p. once daily for 3 wks. The first egg was observed at $42 \mathrm{~d}$ of age (d 42), and the egg laying performance was recorded daily till $\mathrm{d} 52$.

At d 52, quails were sacrificed by cervical dislocation for samples collection and analysis. Serum was collected and stored at $-20^{\circ} \mathrm{C}$, and liver tissues were removed and weighted, and quickly snap-frozen in liquid nitrogen. Frozen tissues were stored at $-70^{\circ} \mathrm{C}$ prior to gene and protein expression analyses. Fifteen frozen tissues were selected randomly (3 samples from each cage) and used for gene and protein expression analyses $(n=15)$.

Animal care and use was approved by the Institutional Animal Care and Use Committee of Nanjing Agricultural University.

\section{Materials}

Kisspeptin-10 (Cat. No. 2570) was purchased from Tocris Bioscience, USA. The contents of TG, Tch, NEFA, apoA1 and apoB were measured by the commercial kits purchased from Beijing Applygen Company (Beijing, China). Moloney Murine Leukemia Virus reverse transcriptase (M-MLV) and RNase inhibitor were products of Promega, USA. Random hexamer primers and dNTP were purchased from TaKaRa, Japan. SYBR Green Realtime PCR Master Mix was product of TOYOBO Ltd., Japan.

\section{Radioimmunoassay for serum $\mathbf{E}_{2}$}

The serum $\mathrm{E}_{2}$ was measured with radioimmunoassay (RIA) using commercial kits purchased from Shanghai Institute of Biological Products. The ranges of assay sensitivity for $\mathrm{E}_{2}$ were between 5 and $4,000 \mathrm{pg} / \mathrm{ml}$. The inter- and intra-assay coefficient of variations were $10 \%$ 
and $15 \%$, respectively.

\section{Gene expression analyses}

Total RNA was extracted from liver tissues using TRIZOL reagent (Takara, Japan). The RNA concentration and quality was then quantified by measuring the absorbance at $260 \mathrm{~nm}$ in a photometer (Eppendorf Biophotometer, Germany). Ratios of absorption (260/280 $\mathrm{nm}$ ) of all preparations were between 1.8 and 2.0. Aliquots of RNA samples were subjected to electrophoresis with $1.4 \%$ agarose-formaldehyde gels stained with ethidium bromide to verify their integrity.

Reverse transcription was performed using the total RNA $(2 \mu \mathrm{g})$ described above in a final volume of $25 \mu \mathrm{l}$ containing 1×RT-buffer, $100 \mathrm{U}$ Moloney Murine Leukemia Virus reverse transcriptase (M-MLV) (Promega, USA), $8 \mathrm{U}$ RNase inhibitor (Promega, USA), $5.3 \mu \mathrm{M}$ random hexamer primers and $0.8 \mathrm{mM}$ dNTP (TaKaRa, Japan). After incubation at $37^{\circ} \mathrm{C}$ for $1 \mathrm{~h}$, the reaction was terminated by heating at $95^{\circ} \mathrm{C}$ for $5 \mathrm{~min}$ and quickly cooling on ice.
Real-time PCR was performed in Mx3000P (Stratagene, USA). Mock RT and No Template Controls (NTC) were set to monitor the possible contamination of genomic DNA both at RT and PCR. The standard curves for each target gene, and melting curves were performed to insure a single specific PCR product for each gene. Two microliter of 16fold dilution of RT product was used for PCR in a final volume of $25 \mu$ l containing $12.5 \mu \mathrm{l} \mathrm{SYBR}$ Green Real-time PCR Master Mix (TOYOBO Ltd., Japan) and 0.6 to $1.0 \mu \mathrm{M}$ of each forward and reverse primers for target genes and internal standard gene (the information of primers was shown in Table 1). Chicken $\beta$-actin mRNA was used as a reference gene for normalization purpose. The following PCR protocols were initial denaturation $\left(1 \mathrm{~min}\right.$ at $\left.95^{\circ} \mathrm{C}\right)$, then a three-step amplification program $\left(20 \mathrm{~s}\right.$ at $95^{\circ} \mathrm{C}, 20$ to $30 \mathrm{~s}$ at 60 to $64^{\circ} \mathrm{C}, 20 \mathrm{~s}$ at $72^{\circ} \mathrm{C}$ ) was repeated 45 times. The PCR products for each gene were sent to Haojia Biotech, Ltd., for sequencing to verify the specificity. The reported sequences exactly matched those published in GenBank. The method of $2^{-\Delta \Delta \mathrm{Ct}}$ was used to analyze the real-time RT-

Table 1. Primer sequences of the target genes

\begin{tabular}{|c|c|c|c|c|}
\hline Target genes & $\begin{array}{c}\text { GenBank } \\
\text { accession number }\end{array}$ & Primer sequences (F: forward, R: reverse) & $\begin{array}{l}\text { PCR products } \\
\text { (bp) }\end{array}$ & $\begin{array}{c}\text { Annealing } \\
\text { temperature }\left({ }^{\circ} \mathrm{C}\right)\end{array}$ \\
\hline$\beta$-actin & NM205518 & $\begin{array}{l}\text { F: 5'-TGCGTGACATCAAGGAGAAG-3' } \\
\text { R: 5'-TGCCAGGGTACATTGTGGTA -3' }\end{array}$ & 300 & 62 \\
\hline SREBP-1 & AY029924 & $\begin{array}{l}\text { F: 5'-CTACCGCTCATCCATCAACG-3' } \\
\text { R: 5'5 } / \text {-CTGCTTCAGCTTCTGGTTGC-3' }\end{array}$ & 145 & 64 \\
\hline FAS & J04485 & $\begin{array}{l}\text { F: 5'-TGAAGGACCTTATCGCATTGC-3' } \\
\text { R: 5'-GCATGGGAAGCATTTTGTTGT -3' }\end{array}$ & 195 & 62 \\
\hline $\mathrm{ACC} \alpha$ & NM-205505 & $\begin{array}{l}\text { F: 5'-AGTCCTGATTGAGCATGGCA-3' } \\
\text { R: 5'-CTCCAGATGGCGGTAGATTC-3' }\end{array}$ & 127 & 62 \\
\hline ME & AF408407 & $\begin{array}{l}\text { F: 5'-AGTGCCTACCTGTGATGTTG-3' } \\
\text { R: 5'-GGCTTGACCTCTGATTCTCT-3' }\end{array}$ & 101 & 62 \\
\hline SCD1 & NM_204890 & $\begin{array}{l}\text { F: 5'-AGTGGTGTTGCTGTGCTTCA-3' } \\
\text { R: 5'-CTAAGGTGTAGCGCAGGATG-3' }\end{array}$ & 107 & 64 \\
\hline HMGCR & AB109635 & $\begin{array}{l}\text { F: 5'- CTGGGTTTGGTTCTTGTTCA -3' } \\
\text { R: 5'-ATTCGGTCTCTGCTTGTTCA -3' }\end{array}$ & 244 & 64 \\
\hline CYP7A1 & AB109636 & $\begin{array}{l}\text { F: 5'-CATTCTGTTGCCAGGTGATGTT-3' } \\
\text { R: 5'-GCTCTCTCTGTTTCCCGCTTT-3' }\end{array}$ & 106 & 64 \\
\hline SREBP-2 & XM_416222 & $\begin{array}{l}\text { F: 5'-CCCAGAACAGCAAGCAAGG-3' } \\
\text { R: 5'-GCGAGGACAGGAAAGAGAGTG-3' }\end{array}$ & 108 & 64 \\
\hline ApoVLDL-II & M25774 & $\begin{array}{l}\text { F: 5'-ATGGTGCAATACAGGGCATT-3' } \\
\text { R: 5'-GGGAAACATCCAGCAAGAAC-3' }\end{array}$ & 196 & 64 \\
\hline FABP2 & AF380999 & $\begin{array}{l}\text { F: 5'-GAGCTCCAGTCCCATGAAAA-3' } \\
\text { R: 5'-TCAGCAGCTCCATCTCACAC-3' }\end{array}$ & 202 & 64 \\
\hline ApoA1 & M17961 & $\begin{array}{l}\text { F: 5'-ATGCCATCGCCCAGTTCG-3' } \\
\text { R: 5'-GAGCCTCGGTGTCCTTCA-3' }\end{array}$ & 162 & 64 \\
\hline VTG-II & M1806 & $\begin{array}{l}\text { F:5'-GCACAAGTGAAGCTGGAGTGG-3' } \\
\text { R: 5'-AATTCTCGAGCACGGCAGAGG-3' }\end{array}$ & 328 & 62 \\
\hline $\mathrm{ER} \alpha$ & X03805 & $\begin{array}{l}\text { F: 5'-GATATTGATGATCGGCTTAG-3' } \\
\text { R: 5'-GTGCTCCATTCCTTTGTT-3' }\end{array}$ & 418 & 62 \\
\hline $\mathrm{ER} \beta$ & AB036415 & $\begin{array}{l}\text { F:5'-GGCAGACAAAGAGCTGGTTCA-3' } \\
\text { R: 5'-TCATGCTCAGCAGATGCTCC-3' }\end{array}$ & 529 & 62 \\
\hline
\end{tabular}


PCR data. All samples were included in the same run of RTPCR and repeated in triplicates.

\section{Western blot analysis}

Liver tissues were immersed in 1,000 $\mu$ l RIPA buffer per $200 \mathrm{mg}$. Homogenated on ice, and then kept antigraded and standed alternately for $30 \mathrm{~min}$. RIPA buffer contained $50 \mathrm{mM}$ Tris base (pH 7.4), $150 \mathrm{mM} \mathrm{NaCl}, 1 \mathrm{mM}$ EDTA, $1 \%$ (v/v) NP-40, $0.25 \%$ (w/v) Na-deoxycholate, $1 \mathrm{mM} \mathrm{NaF}$, and $1 \%(\mathrm{v} / \mathrm{v})$ Halt protease inhibitor cocktail (Pierce Chemical Co., Rockford, IL, USA). Tissue lysates were centrifuged at $12,000 \mathrm{rpm}$ for $10 \mathrm{~min}$ and the supernatant was removed. The pellet was dissolved in lysed buffer and the protein concentration was determined with the BCA (bicinchoninic acid) Protein Assay Kit (Pierce Chemical Corp., Rockford, USA). Samples were all denatured at $100^{\circ} \mathrm{C}$ for $5 \mathrm{~min}$ before loaded into a $12 \%$ polyacrylamide gel, and then transferred onto a polyvinylidene difluoride membrane (Immobilon-P, Millipore Corp., Fisher Scientific, Hanover Park, IL, USA) at 100 voltages for $90 \mathrm{~min}$. The membrane was then blocked with $3 \%(\mathrm{~m} / \mathrm{v})$ BSA for $2 \mathrm{~h}$. After that, the membranes were incubated with primary antibodies (SREBP-1 at 1:100 dilution; SREBP-2 at 1:200 dilution; $\mathrm{ER} \alpha$ at 1:500 dilution and GAPDH at 1:10,000 dilution) at $4^{\circ} \mathrm{C}$ for $16 \mathrm{~h}$. After washing, the membranes were incubated with horseradish peroxidase-conjugated anti-mouse IgG secondary antibody for $2 \mathrm{~h}$ at room temperature. The immunoblots were visualized by enhanced chemiluminescence detection (Pierce Chemical Corp., Rockford, USA) and quantified by integrated focal imaging system. The band densities of SRBBP-1, SREBP-2 and $\mathrm{ER} \alpha$ were normalized with that of GAPDH. Antibody of SREBP-1, SREBP-2 and ER $\alpha$ were all purchased from Abcam Company, Cambridge, UK, the catalog No. are ab3259, ab30682 and ab2746 respectively. Antibody of GAPDH was bought from Kangchen Company, Shanghai, China, and the catalog No. is KC-5G4.

\section{Statistical analysis}

The results are expressed as mean \pm SEM. Data were analyzed by ANOVA using the General Linear Models of SPSS 11.0 for Windows (StatSoft, Inc. USA). The effects of $\mathrm{Kp}-10$ on TG and cholesterol and genes expression data were analyzed by one-way ANOVA followed by least significant difference test post hoc analysis. Data were considered statistically significant when $\mathrm{p}<0.05$.

\section{RESULTS}

\section{Serum $E_{2}$ concentration and lipid metabolic parameters}

Serum $\mathrm{E}_{2}$ concentration was markedly increased by $\mathrm{Kp}$ 10 injection on dose-dependent manner, and reaching the statistical significance in $\mathrm{H}$ group $(\mathrm{p}<0.05)$. The level of serum triglyceride (TG) was increased by $46.7 \%$ in L group and $36.8 \%$ in $\mathrm{H}$ group, respectively, but did not reach the statistical significance $(p>0.05)$, while the content of TG in liver was significantly elevated by $\mathrm{Kp}-10$ injection in a dose-dependent manner in $\mathrm{L}$ and $\mathrm{H}$ group compared to the control group $(\mathrm{p}<0.05)$. Compared to the control group, serum total cholesterol (Tch) concentration was significantly decreased in $\mathrm{H}$ group $(\mathrm{p}<0.05)$, while the hepatic Tch content was markedly increased by high dosage of Kp-10 administration ( $\mathrm{p}<0.05)$. There were no significant changes of serum or hepatic Tch content in L group $(p>0.05)$. The levels of non-esterified fatty acid (NEFA), apolipoprotein A-I (apoA1) and apolipoproteins B (apoB) were not altered by chronic Kp-10 injection $(\mathrm{p}>0.05)$ (Table 2).

\section{Hepatic expression of genes involved in lipids metabolism}

As shown in Figure 1 to 4, the genes expression of SREBP-1, FAS, ApoVLDL-II, CYP7A1 and VTG-II in liver were significantly up-regulated in $\mathrm{H}$ but not $\mathrm{L}$ group compared to the Con group ( $\mathrm{p}<0.05)$. SREBP-2, $\mathrm{ACC}_{\alpha}, \mathrm{ME}$, SCD1, ApoA1, FABP2, HMGCR, ER $\alpha$ and $\beta$ mRNA

Table 2. Effects of kp-10 on the contents of parameters in serum and liver

\begin{tabular}{lccc}
\hline & Con & $\mathrm{L}$ & $\mathrm{H}$ \\
\hline In serum & & & $2.443 \pm 0.088^{\mathrm{b}}$ \\
Tch $(\mathrm{mg} / \mathrm{ml})$ & $2.781 \pm 0.115^{\mathrm{a}}$ & $26.498 \pm 4.697$ & $24.758 \pm 3.484$ \\
TG $(\mathrm{mg} / \mathrm{ml})$ & $18.098 \pm 3.761$ & $3.47 \pm 0.56$ & $3.93 \pm 0.39$ \\
NEFA (mmol/L) & $3.82 \pm 0.63$ & $0.11 \pm 0.04$ & $0.10 \pm 0.05$ \\
apoA1 (g/L) & $0.10 \pm 0.03$ & $0.40 \pm 0.08$ & $0.35 \pm 0.06$ \\
apoB (g/L) & $0.35 \pm 0.04$ & $703.82 \pm 27.72^{\mathrm{a}}$ & $777.54 \pm 22.77^{\mathrm{b}}$ \\
E $_{2}$ concentration $(\mathrm{pg} / \mathrm{ml})$ & $633.15 \pm 68.02^{\mathrm{a}}$ & $32.27 \pm 4.00^{\mathrm{b}}$ & $37.68 \pm 4.07^{\mathrm{a}}$ \\
In liver & & $17.13 \pm 0.91^{\mathrm{b}}$ & $23.63 \pm 1.51^{\mathrm{b}, * *}$ \\
Tch $(\mathrm{mg} / 100 \mathrm{~g})$ & $28.07 \pm 3.81^{\mathrm{b}}$ & $13.10 \pm 0.31^{\mathrm{a}}$ & \\
TG $(\mathrm{mg} / 100 \mathrm{~g})$ &
\end{tabular}

All values were mean \pm SE, $n=25$, Means within rows with different letter superscripts are significantly different ( $\mathrm{p}<0.05$ ), and $* *$ at the level of $\mathrm{p}<0.01$ (compared with control). 


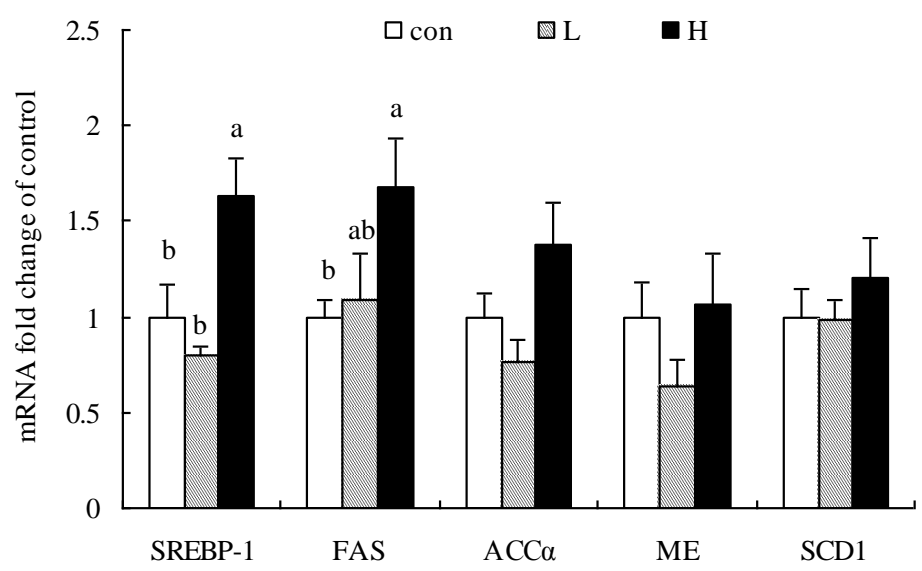

Figure 1. Effects of Kp-10 on the hepatic expression of lipogenic genes including SREBP-1, FAS, ACC $\alpha$, ME and SCD1 mRNA in quails. Values are means \pm SE of fifteen replications. The data points without same superscripts $(a, b)$ are significantly different (one-way ANOVA) at the level of $\mathrm{p}<0.05$ by least square difference tests.

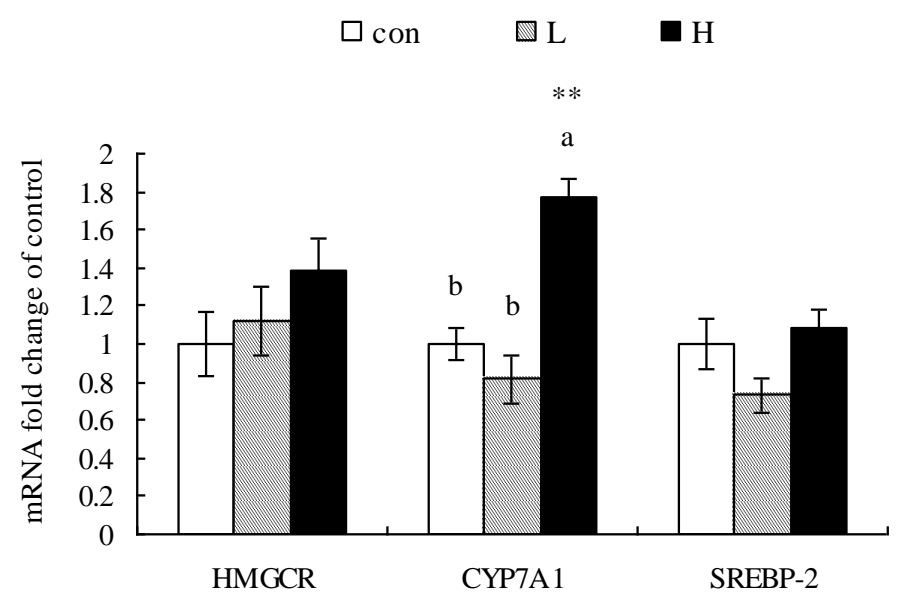

Figure 2. Effects of Kp-10 on the hepatic expression of cholesterol metabolic genes including HMGCR, CYP7A1 and SREBP-2 mRNA in quails. Values are means \pm SE of fifteen replications. The data points without same superscripts $(\mathrm{a}, \mathrm{b})$ are significantly different (oneway ANOVA) at the level of $\mathrm{p}<0.05$ by least square difference tests.

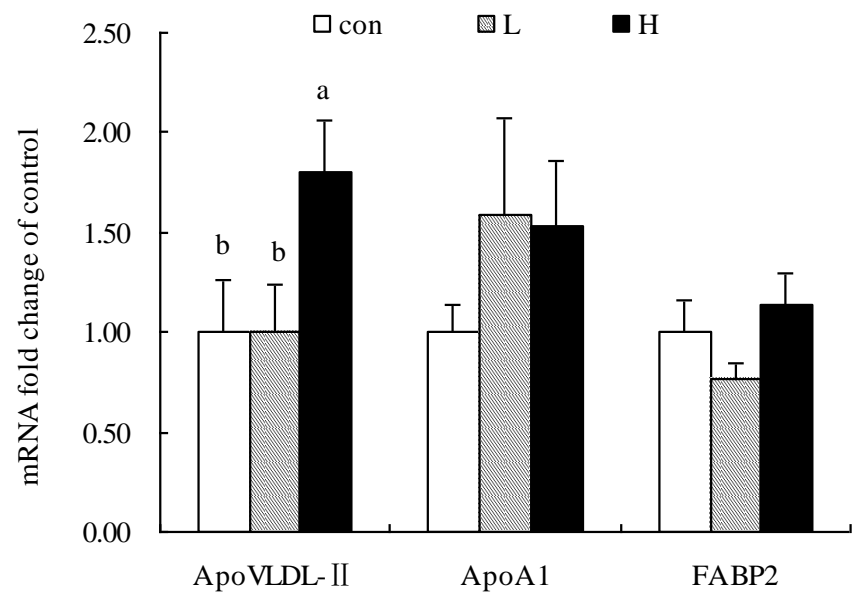

Figure 3. Effects of Kp-10 on the hepatic expression of lipids transporting genes including ApoVLDL-II, ApoA1 and FABP2 mRNA in quails. Values are means \pm SE of fifteen replications. The data points without same superscripts $(a, b)$ are significantly different (one-way ANOVA) at the level of $\mathrm{p}<0.05$ by least square difference tests. 


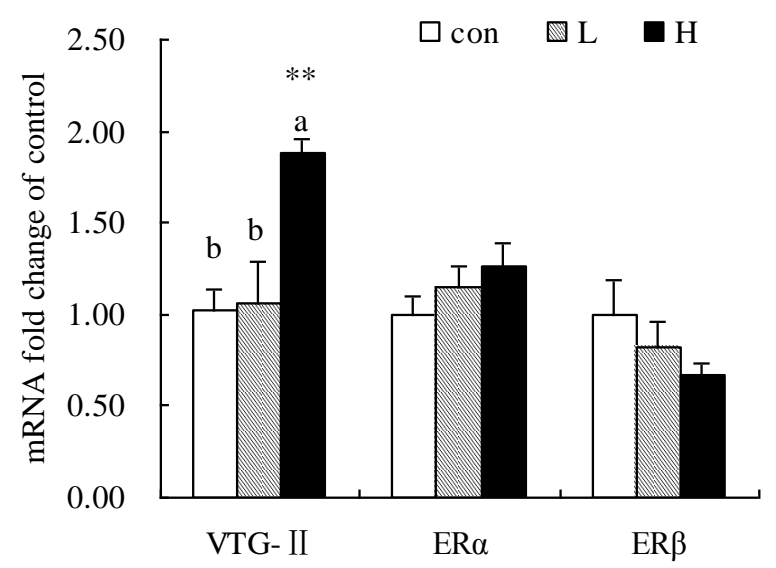

Figure 4. Effects of Kp-10 on the hepatic expression of VTG-II, $\mathrm{ER} \alpha$ and $\mathrm{ER} \beta$ mRNA in quails. Values are means $\pm \mathrm{SE}$ of fifteen replications. The data points without same superscripts (a, b) are significantly different (one-way ANOVA) at the level of $\mathrm{p}<0.05$ and $* *$ at the level of $\mathrm{p}<0.01$ (compared with control) by least square difference tests.

expressions were not altered by $\mathrm{Kp}-10$ treatment (p>0.05)(Figures 1, 2, 3 and 4).

\section{Correlation analyses among genes expression}

Some of the significant correlations were found among genes encoding hepatic enzymes linked with lipogenic pathway. Table 3 showed that SREBP-1 gene expression was positively correlated with FAS and ACC $\alpha$ genes $(\mathrm{p}<0.01)$. ACC- $\alpha$ mRNA expression in liver was positively correlated with the genes expression of SREBP-1, FAS, ME and SCD1 $(\mathrm{p}<0.05)$. As shown in Table 4, there was a highly positive correlation between apoVLDL-II and VTGII genes expression in liver $(p<0.01)$. There was a mild correlation between $\mathrm{E}_{2}$ level and VTG-II mRNA expression $(\mathrm{p}<0.1)$, between ER $\alpha$ and VTG-II $(p<0.1), E R \alpha$ and apoVLDL-II mRNA expression ( $\mathrm{p}<0.05)$ (Tables 3 and 4).

\section{Hepatic SREBP-1, -2 and ER $\alpha$ protein content}

Hepatic protein content of SREBP-1, 2 and ER $\alpha$ was determined with Western blot analysis and shown in Figure 5. In line with hepatic mRNA abundance, hepatic SREBP-1 content was significantly higher in $\mathrm{H}$ group than the control group. ER $\alpha$ Protein content in liver was also significantly increased by high dosage of $\mathrm{Kp}-10$, although its mRNA expression was not altered by $\mathrm{Kp}-10$ treatment. However, no obvious changes of SREBP-2 protein expression in liver were observed in quails among the Con, $\mathrm{L}$ and $\mathrm{H}$ groups (Figure 5).

\section{DISCUSSION}

In this study, we reported herein the effects of kisspeptin-10 on regulating the initiation of egg laying in

Table 3. Correlations between expressions of hepatic genes related to lipid synthesis

\begin{tabular}{|c|c|c|c|c|c|}
\hline & SREBP-1 & FAS & ACC- $\alpha$ & $\mathrm{ME}$ & SCD1 \\
\hline & ---- & $-\cdots$ & $\mathrm{r}($ & 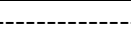 & 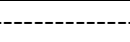 \\
\hline \multirow[t]{2}{*}{ SREBP-1 } & 1 & 0.51662 & 0.5629 & 0.35621 & 0.28955 \\
\hline & & (0.0049) & $(0.0034)$ & $(0.0579)$ & $(0.1604)$ \\
\hline \multirow[t]{2}{*}{ FAS } & & 1 & 0.50073 & 0.28652 & 0.47762 \\
\hline & & & $(0.0108)$ & $(0.1394)$ & $(0.0158)$ \\
\hline \multirow[t]{2}{*}{ ACC- $\alpha$} & & & 1 & 0.58708 & 0.69372 \\
\hline & & & & $(0.0020)$ & $(0.0001)$ \\
\hline \multirow[t]{2}{*}{ ME } & & & & 1 & 0.36621 \\
\hline & & & & & $(0.0718)$ \\
\hline SCD1 & & & & & 1 \\
\hline
\end{tabular}

Pearson's correlation coefficients (r) are shown with $\mathrm{p}$ values in parentheses.

Table 4. Correlations between expressions of hepatic genes related to lipid synthesis and transporting to egg yolk

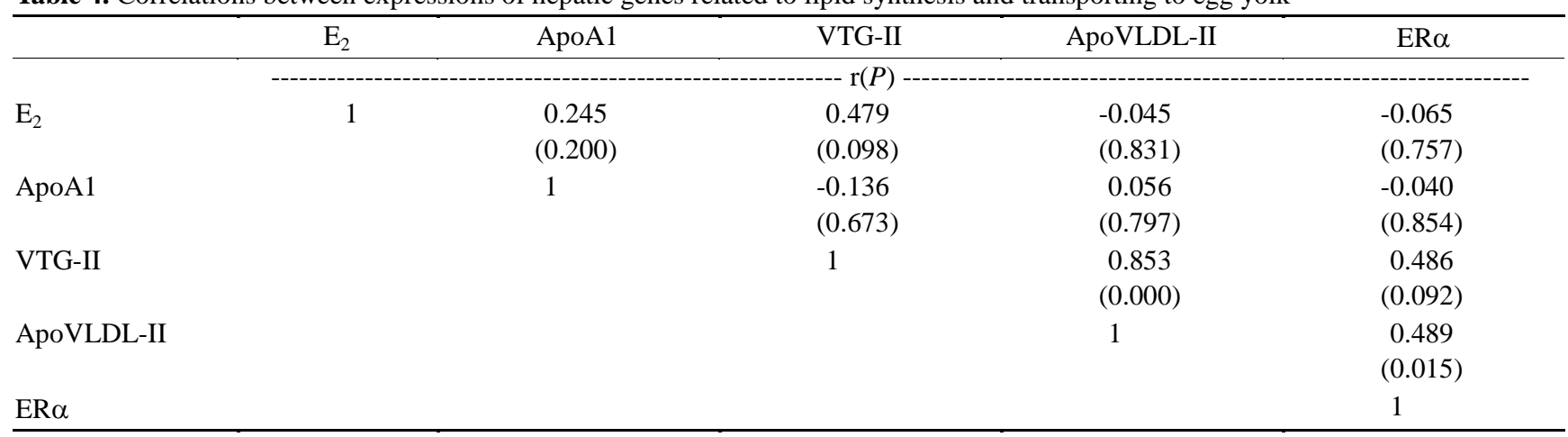

Pearson's correlation coefficients (r) are shown with $\mathrm{p}$ values in parentheses. 


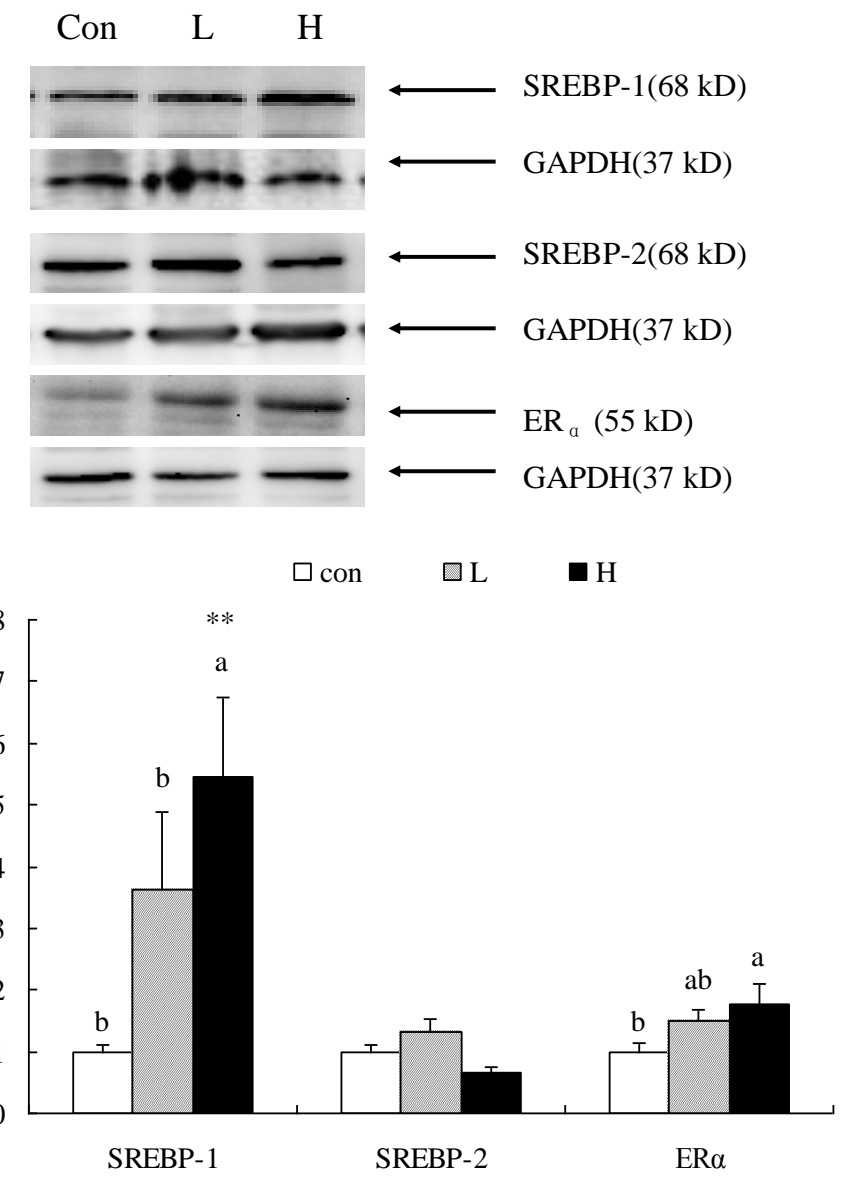

Figure 5. Effects of Kp-10 on the hepatic expression of SREBP-1, SREBP-2 and ER $\alpha$ proteins in quails. Values are means \pm SE of fifteen replications. The data points without same superscripts $(a, b)$ are significantly different (one-way ANOVA) at the level of $\mathrm{p}<0.05$ and $* *$ at the level of $\mathrm{p}<0.01$ (compared with control) by least square difference tests.

quails for the first time. Our previous results showed that daily i.p. injection of kisspeptin-10 with 10 or $100 \mathrm{nmol}$ to juvenile female quails for 3 wks notably evoked an earlier onset of egg laying (Ni et al., 2012). In this study, we found that there was a significant increase in lipids synthesis in liver, as well as the significant up-regulation of estrogen receptor protein and lipogenic genes expression in liver.

Kisspeptin encoded by Kiss- 1 gene acts as the GnRH secretagogue to play a critical role in the physiology of puberty in mammals (Navarro, 2005). The avian neuroendocrine and endocrine system is very similar to the mammalian system (Wingfield, 2005). Although there is no evidence for a Kiss-like gene in birds, and even this gene is suggested to be lost in avian species during evolution (Akazome et al., 2010), kisspeptin-like immunoreactivity (i.r) has been described in the central brain of Mallard drake (Saldanha et al., 2010). Intracerebroventricular injection of kisspeptin-10 into drake brain elicited a robust increase in circulating LH levels (Saldanha et al., 2010). Our results showed that consecutive $\mathrm{Kp}-10$ injection significantly increased estrogen secretion and HPG axis activity (Ni et al., 2012), showing a similar biological effect of kisspeptins on reproduction in birds as in mammals.

In all egg-laying vertebrates, there are a large amount of lipids transported to and stored in egg yolk. In chicken, each egg contains about 4 gram triglyceride (Bujo et al., 1997), thus the initiation and maintenance of egg production is an energy-intensive process and requires a large quantity of lipids (especially triglyceride) for egg yolk forming. There is fairly low lipid content in avian diets and lipogenesis in liver is the major path for lipid depositing in the adipose tissue and ovary of female poultry (Richards et al., 2003). Our results showed that paralleling with a higher rate of egg laying, Kp-10 injection significantly increased the contents of TG and Tch in livers of female quails, suggesting an improvement of hepatic lipogenesis. In the present study, the contents of Tch and TG in liver were significantly higher in $\mathrm{H}$ group than that in Con chickens. The increase of Tch in liver and the decrease of Tch in circulating system might contribute to transport more lipids to the follicles to form egg yolk.

In this study, high dosage of $\mathrm{Kp}-10$ injections significantly increased the expression of SREBP-1c and FAS mRNA and protein synthesis of SREBP-1c in liver. 
There were strong positive correlations of SREBP-1 gene expression with ACC $\alpha$ and FAS genes expression in liver, respectively. The up-regulation of SREBP-1c and FAS genes expression may account for the higher contents of TG in liver as well as in blood. Moreover, the expression of hepatic apoVLDL-II gene in $\mathrm{H}$ group was also significantly increased. ApoVLDL-II is a major apolipoprotein in plasma VLDL in laying hens and in estrogen-treated cockerels and roosters (Codina-Salada et al., 1983). Besides, ApoVLDL-II may inhibit the activities of lipoprotein lipase (LPL) (Walzem et al., 1999), then to protect the triglycerides from decomposing. It is produced exclusively in the liver in response to estrogen treatment. The mRNA expression of ApoVLDL-II increases markedly after estrogen treatment (Codina-Salada et al., 1983).

Vitellogenin (VTG), a precursor yolk protein (Tata, 1976), is synthesized in the liver under estrogenic induction (Le Menn et al., 1980; Wallace and Selman, 1985). Although the changes of VTG-II mRNA expression during different egg laying cycles have not been reported in birds, the age-related studies on the VTG-II gene of Japanese quail was presented by Gupta et al. (2006). In birds, the timing of VTG-II gene expression parallels with that of egg laying. In this study, accompanied by higher level of $E_{2}$ in circulation VTG-II gene expression in liver was increased significantly in $\mathrm{H}$ group. In addition, there are mild correlations between $\mathrm{E}_{2}$ and VTG-II mRNA expression, as well as ER $\alpha$ and VTG-II expressions. Positive correlations were also observed between ER $\alpha$ and apoVLDL-II, ApoA1 and apoB, ApoVLDL-II and VTG-II genes expression in liver.

In summary, we reported herein the first time that consecutive injections of kisspeptin-10 with 10 or $100 \mathrm{nmol}$ to juvenile female quails notably evoked an earlier onset of egg laying, which paralleled with an improvement in TG and Tch synthesis in liver. The increase in hepatic lipogenic synthesis was associated with the up-regulation of hepatic SREBP-1, FAS, ApoVLDL-II and VTG-II genes expression.

\section{ACKNOWLEDGEMENTS}

This work was supported by National Nature Science Foundation of China (Project No. 30800809), A Project Funded by the Priority Academic Program Development of Jiangsu Higher Education Institutions (PAPD) and the Fundamental Research Funds for the Central Universities (KYZ201212).

\section{REFERENCES}

Akazome, Y., S. Kanda, K. Okubo, and Y. Oka. 2010. Functional and evolutionary insights into vertebrate kisspeptin systems from studies of fish brain. J. Fish Biol. 76:161-182.

Bujo, H., M. Hermann, K. A. Lindstedt, J. Nimpf, and W. J. Schneider. 1997. Low density lipoprotein receptor gene family members mediate yolk deposition. J. Nutr. 127:801-804.

Charlier, T. D., A. E. Newman, S. A. Heimovics, K. W. Po, C. J. Saldanha, and K. K. Soma. 2011. Rapid effects of aggressive interactions on aromatase activity and oestradiol in discrete brain regions of wild male white-crowned sparrows. J. Neuroendocrinol. 23:742-753.

Clarkson, J., and A. E. Herbison. 2006. Postnatal development of kisspeptin neurons in mouse hypothalamus; sexual dimorphism and projections to gonadotropin-releasing hormone neurons. Endocrinology 147:5817-5825.

Codina-Salada, J., J. P. Moore, and L. Chan. 1983. Kinetics of primary and secondary stimulation of the mRNA for APOVLDL-II, a major yolk protein, in the cockerel liver by estrogen. Endocrinology 113:1158-1160.

d'Anglemont de, T. X., L. A. Fagg, J. P. C. Dixon, K. Day, H. G. Leitch, A. G. Hendrick, D. Zahn, I. Franceschini, A. Caraty, M. B. Carlton, S. A. Aparicio, and W. H. Colledge. 2007. Hypogonadotropic hypogonadism in mice lacking a functional Kiss1 gene. Proc. Natl. Acad. Sci. USA. 104:10714-10719.

de Roux, N. 2003. Hypogonadotropic hypogonadism due to loss of function of the KiSS1-derived peptide receptor GPR54. Proc. Natl. Acad. Sci. USA. 100:10972-10976.

Gupta, S., R. U. Pathak, and M. S. Kanungo. 2006. DNA methylation induced changes in chromatin conformation of the promoter of the vitellogenin II gene of Japanese quail during aging. Gene 377:159-168.

Gous, R. M., G. D. Bradford, S. A. Johnson, and T. R. Morris. 2000. Effect of age of release from light or food restriction on age at sexual maturity and egg production of laying pullets. Br. Poult. Sci. 41:263-271.

Han, S. K., M. L. Gottsch, K. J. Lee, S. M. Popa, J. T. Smith, S. K. Jakawich, D. K. Clifton, R. A. Steiner, and A. E. Herbison. 2005. Activation of gonadotropin-releasing hormone neurons by kisspeptin as a neuroendocrine switch for the onset of puberty. J. Neurosci. 25:11349-11356.

Hermier, D. 1997. Lipoprotein metabolism and fattening in poultry. J. Nutr. 127:805-808.

Keen, K. L., F. H. Wegner, S. R. Bloom, M. A. Ghatei, and E. Terasawa. 2008. An increase in kisspeptin-54 release occurs with the pubertal increase in luteinizing hormone-releasing hormone-1 release in the stalk-median eminence of female rhesus monkeys in vivo. Endocrinology 149:4151-4157.

Kotani, M., M. Detheux, A. Vandenbogaerde, D. Communi, J. M. Vanderwinden, E. Le Poul, S. Brézillon, R. Tyldesley, N. Suarez-Huerta, F. Vandeput, C. Blanpain, S. N. Schiffmann, G. Vassart, and M. Parmentier. 2001. The metastasis suppressor gene KiSS-1 encodes kisspeptins, the natural ligands of the orphan G protein-coupled receptor GPR54. J. Biol. Chem. 276:34631-34636.

Le Menn, F., H. Rochefort, and M. Garcia. 1980. Effect of androgen mediated by the estrogen receptor of fish liver: vitellogenin accumulation. Steroids 35:315-328.

Navarro, V. M. 2005. Effects of KiSS-1 peptide, the natural ligand of GPR54, on follicle-stimulating hormone secretion in the rat. Endocrinology 146:1689-1697. 
Ni, Y. D., Y. B. Huang, Y. Q. Xiao, J. Wu, F. Y. Qian, R Grossmann, and R. Q. Zhao. 2012. Effects of repeated injection of kisspeptin-10 on the initiation of egg-laying in juvenile quail. Anim. Reprod. Sci. 134:203-209.

Oakley, A. E., D. K. Clifton, and R. A. Steiner. 2009. Kisspeptin signaling in the brain. Endocr. Rev. 30:713-743.

Ottinger, M. A., M. Abdelnabi, Q. Li, K. Chen, N. Thompson, N. Harada, C. Viglietti-Panzica, and G. C. Panzica. 2004. The Japanese quail a model for studying reproductive aging of hypothalamic systems. Exp. Gerontol. 39:1679-1693.

Richards, M. P., S. M. Poch, C. N. Coon, R. W. Rosebrough, C. M. Ashwell, and J. P. McMurtry. 2003. Feed restriction significantly alters lipogenic gene expression in broiler breeder chickens. J. Nutr. 133:707-715.

Roa, J., J. M. Castellano, V. M. Navarro, D. J. Handelsman, L. Pinilla, and M. Tena-Sempere. 2009. Kisspeptins and the control of gonadotropin secretion in male and female rodents. Peptides 30:57-66.

Saldanha,C. J., B. J. Walters, and G. S. Fraley. 2010. Neurons that co-localize aromatase- and kisspeptin-like immunoreactivity may regulate the HPG axis of the Mallard drake (Anas platyrhynchos). Gen. Comp. Endocrinol. 166:606-613.

Seminara, S. B., S. Messager, E. E. Chatzidaki, R. R. Thresher, J. S. Acierno, J. K. Shagoury, Y. Bo-Abbas, W. Kuohung, K. M. Schwinof, A. G. Hendrick, D. Zahn, J. Dixon, U. B. Kaiser, S. A. Slaugenhaupt, J. F. Gusella, S. O'Rahilly, M. B. Carlton, W. F. Crowley, S. A. Aparicio, and W. H. Colledge. 2003. The GPR54 gene as a regulator of puberty. N. Engl. J. Med. 349:1614-1627.

Smith, J. T., H. M. Dungan, E. A. Stoll, M. L. Gottsch, R. E. Braun, S. M. Eacker, D. K. Clifton, and R. A. Steiner. 2005. Differential regulation of KiSS-1 mRNA expression by sex steroids in the brain of the male mouse. Endocrinology 146:2976-2984.
Tata, J. R. 1976. The expression of the vitellogenin gene. Cell 9:114.

Um, H. N., J. M. Han, J. I. Hwang, S. I. Hong, H. Vaudry, and J. Y. Seong. 2010. Molecular coevolution of kisspeptins and their receptors from fish to mammals. Ann. N.Y. Acad. Sci. 1200: 67-74.

van Aerle, R., P. Kille, A. Lange, and C. R. Tyler. 2008. Evidence for the existence of a functional Kiss1/Kiss1 receptor pathway in fish. Peptides 29:57-64.

Wallace, R. A., and K. Selman. 1985. Major protein changes during vitellogenesis and maturation of Fundulus oocytes. Dev. Biol. 110:492-498.

Walzem, R. L., R. J. Hansen, D. L. Williams, and R. L. Hamilton. 1999. Estrogen induction of VLDLy assembly in egg-laying hens. J. Nutr. 129:467-472.

Wingfield, J. C. 2005. Historical contributions of research on birds to behavioral neuroendocrinology. Horm. Behav. 48:395-402.

Wilson, S. B., D. W. Back, S. M. Morris, J. Swierczynski, and A. G. Goodridge. 1986. Hormonal regulation of lipogenic enzymes in chick embryo hepatocytes in culture. Expression of the fatty acid synthase gene is regulated at both translational and pretranslational steps. J. Biol. Chem. 261:15179-15182.

Xiao, Y., Y. D. Ni, Y. B. Huang, J. Wu, R. Grossmann, and R. Q. Zhao. 2011. Effects of kisspeptin-10 on progesterone secretion in cultured chicken ovarian granulosa cells from preovulatory $\left(\mathrm{F}\left({ }_{1}\right)-\mathrm{F}(3)\right)$ follicles. Peptides 32:2091-2097.

Xu, Z. R., M. Q. Wang, H. X. Mao, X. A. Zhan, and C. H. Hu. 2003. Effects of L-carnitine on growth performance, carcass composition, and metabolism of lipids in male broilers. Poult. Sci. 82:408-413. 